\title{
Relevant but Delayed Information in Negotiated Audit Fees: Evidence from Stock Price Crashes
}

\author{
Karl Hackenbrack ${ }^{a}$, Nicole Thorne Jenkins ${ }^{a}$ and Mikhail Pevzner \\ ${ }^{a}$ Owen School of Management, Vanderbilt University; 401 21st Ave. South; Nashville, TN 37203-2422 \\ ${ }^{\mathrm{b}}$ George Mason University, School of Management; 4400 University Drive, MS 5F4; Fairfax, VA 22030
}

Current Draft: November 2011

\begin{abstract}
Audit fee negotiations conclude the first quarter of the year under audit, yet the audit fee is not disclosed until the first quarter of the following year. We conjecture that negotiated audit fees impound auditor's consequential private, client-specific knowledge about events investors will eventually learn. We demonstrate that year-to-year changes in audit fees have an economically meaningful positive association with proxies for idiosyncratic risk-future negative stock performance (crashes, skewness, and volatility), debt downgrades and lawsuits. This relation holds in the year under audit as well as the following year. The results suggest that negotiated audit fees contain information meaningful to investors that if disclosed when known instead of in the following year, would reduce information asymmetry.
\end{abstract}

JEL classification: G19, D89, M40

Keywords: Crashes, Audit fees, disclosure

Data: Available from public sources identified in the text.

Corresponding author: Tel (615) 343-0553 office; Fax (615) 343-7177 (Nicole Thorne Jenkins)

E mail addresses: $\quad$ Nicole.Jenkins@,vanderbilt.edu (Nicole Thorne Jenkins) 


\section{Introduction}

Information opaqueness occurs. For example, Kothari, Shu and Wysocki (2009)

document that managers withhold bad news from investors up to a certain threshold. When such accumulated bad news reaches a "tipping point", the company experiences an extreme negative stock price return — a crash (Jin and Myers, 2006; Hutton, Marcus and Tehranian, 2009; Kim, Li and Zhang 2010). The revelation of bad news is a shock to investors, but it is less likely to surprise a company's auditor because she has access to a broad array of client-specific information well before investors. In this paper we investigate the possibility that auditors are able to predict crash events in their clients and price audits accordingly, and whether prompt disclosure of the audit fee would result in more timely communication of information buildups that lead to "tipping points".

An auditor's private, client-specific information is impounded in the negotiated audit fee (Hribar, Kravet and Wilson 2010 and Picconi and Reynolds 2010). Her private information affects the negotiated fee in two ways. First, changes in a client are central to estimating the amount and mix of labor needed to complete the engagement. Second, when changes in client conditions cannot be adequately addressed by altering the amount or mix of labor, she price protects by increasing the risk premium component of the audit fee. ${ }^{1}$ The more significant the change in a client's circumstances, the more pronounced the change in the negotiated audit fee.

The auditor and client conclude their audit fee negotiation and sign an engagement letter the first quarter of the fiscal year to be audited, typically before the prior year's earnings release

\footnotetext{
${ }^{1}$ For example, no amount of auditing can protect an auditor should the financial viability of a client be threatened by heightened suspicion that ongoing research and development projects are not likely to generate future positive cash flows.
} 
date (see figure 1$).{ }^{2}$ The engagement letter is a fixed fee contract. The negotiated audit fee is very sticky and can only be changed in response to significant unexpected changes in the scope of work performed, such as work associated with an unexpected acquisition or an unexpected internal control issue, and only by mutual agreement of the auditor and the client. Because it is so difficult to alter the fee articulated in the engagement letter, auditors spend a great deal of time pre-audit in consultation with their clients considering the influence of new developments in the literature, client's operations, client industry, and in the economy. As a result, the negotiated fee impounds a wealth of private, client-specific information.

Market participants learn the audit fee paid retrospectively in the first quarter of the fiscal year following the year audited. ${ }^{3}$ As a result, roughly a year lapses between the auditor-client fee negotiation and investors learning the audit fee. Should the negotiated fee reflect the accumulation of the auditor's private, client-specific knowledge, then significant changes in the negotiated audit fee might be diagnostic of a fundamental change in the client which is not yet publicly known, but economically meaningful to investors.

In this paper, we empirically examine the relation between year-to-year changes in the audit fee and stock price crashes that occur over the roughly 12 months between the negotiation and disclosure of the audit fee. The year-to-year change in the audit fee is a measure of company-specific opacity, private, client-specific knowledge, known to management and the auditor which eventually is revealed to investors through existing channels. Stock price crashes

\footnotetext{
${ }^{2}$ Auditing standards (AU311) require that auditors document their understanding of the terms of an engagement in a contract called an engagement letter.

${ }^{3}$ As of February 5, 2001, companies are required to disclose fees paid to the incumbent auditor for services (audit and non-audit) rendered the prior fiscal year in their proxy statement. The fee information is incorporated by reference into Part III of the company's 10K. Effective for fiscal years ending after December 15, 2003, if the proxy is not filed within 120 days of the company's year-end, the fee disclosure must be separately stated in the $10 \mathrm{~K}$. Proxies are governed by Regulation 14a of the General Rules and Regulations promulgated under the SEC Act of 1934.
} 
represent investors' response to companies reaching a "tipping point" and proxies for the market realization of idiosyncratic risk (Hutton et al. 2009). Examples include missing market expectations, being investigated by a governmental agency, a product failure, etc. Should yearto-year changes in the audit fee (company-specific opacity) be related to stock price crashes (realization of idiosyncratic risk), then prompt disclosure of the negotiated audit fee would result in more timely communication of the information buildups that lead to "tipping points".

We find in a large sample of public company annual audits for the period 2001 through 2010 that the change in audit fees is positively associated with measures of idiosyncratic risk realized over the roughly 12 months between the negotiation and disclosure of the audit fee. After controlling for client changes generally associated with increases in audit effort, we find companies that experience a stock price crash can expect its auditor to have negotiated a 5 percentage point increase in the industry-adjusted audit fee in advance of a crash event. We obtain similar results using two traditional proxies for the realization of company-specific bad news: credit rating downgrades and the filing of a class action security lawsuit. In a set of additional tests, we find evidence of a positive association between changes in audit fees and measures of idiosyncratic risk realized in the year following the year under audit. Thus, auditors appear to predict "tipping points" for both the year under audit and the following year and engage in a form of price protection.

Only managers and auditors know the negotiated audit fee prior to the realizations of the idiosyncratic risk measures examined. Investors learn the audit fee paid in the definitive proxy statement filed after the observed realizations of idiosyncratic risk. Consequently, companyspecific opacity is greater than perhaps necessary and the market is precluded from assimilating timely, consequential information embedded in the negotiated audit fee simply because the 
current mandate is to disclose audit fee information essentially one year after it is known by insiders. Information processing costs or lack of timely disclosure mechanisms are not a barrier to timely disclosure as the negotiated audit fee is objective, stated in the engagement letter, and known when the definitive proxy statement is filed the first quarter of the year under audit. We do not address in this study how timely disclosure would complicate the auditor-auditee fee negotiation process, and more generally the auditor-client relationship.

The remainder of the paper proceeds as follows. Section two discusses the prior literature in the area as well as our research design. Our sample selection and descriptive statistics are presented in section three. The multivariate results are presented in section four and our additional analysis is in section five. Section six contains concluding remarks.

\section{Prior Literature and Research Design}

\subsection{Disclosure and Information Asymmetry}

Both the theoretical and empirical research posit that the more relevant and higher the quality of information that is available to shareholders the better. Increased disclosure quality has been theoretically linked to decreases in both information asymmetry and cost of capital and to an increase in liquidity (Diamond and Verrecchia 1991, Kim and Verrecchia 1994, Lambert et al., 2007). Empirically, increased disclosure quality has also been linked to increases in liquidity and analyst following (Botosan 1997; Sengupta 1998, Healy and Palepu 2001; Botosan and Plumlee 2002; Lang and Lundholm 1996; Pevzner, 2007) and decreases in cost of capital (Frankel et al. 1995; Welker, 1995; Heflin et al. 2005; Botosan 1997; Lang and Lundholm 2000 and Botosan and Plumlee 2002). These findings are consistent with the notion that greater levels of disclosure quality reduce the risk associated with estimating future cash flows, thus lowering 
the return demanded by investors. Moreover, increased disclosure quality is thought to decrease information asymmetry by aligning the information that investors have with that of managers. To the extent that the negotiated audit fee impounds client-specific information known to managers but not investors, prompt disclosure of the negotiated audit fee will reduce manager/investor information asymmetry and, consequently, benefit stakeholders.

Information asymmetry is akin to the concept of opacity. In Jin and Myers' (2006) model, less transparent or equivalently more opaque companies are more likely to experience significant stock price crashes. Their proxy for opacity is the development level of the financial system in the country where a company is domiciled. They find that companies residing in countries with less well developed financial systems are more likely to experience crashes in their stock price. Hutton, Marcus and Tehranian (2009) also examine the relation between opacity and stock price crashes. They use earnings management, as proxied by discretionary accruals, as an indicator of opacity and find that opaque companies are better able to conceal company-specific information than non-opaque companies, i.e., have higher levels of information asymmetry and idiosyncratic risk. Their results demonstrate that companies that engage in earnings management are able to stock pile bad news up to a "tipping point" that, when crossed, results in a stock price crash. Hutton et al. (2009) find that following the adoption of the Sarbanes Oxley Act (2002) discretionary accruals ceases to serves as a viable proxy for opacity. Recent work by $\mathrm{Kim}, \mathrm{Li}$, and Zhang (2010) provides additional evidence of the relation between opacity and idiosyncratic risk by showing that tax avoidance is positively related to stock price crash risk.

Our investigation is most similar to Hutton et al. (2009) and Kim et al. (2010). We add to this developing literature by studying the relation between a new proxy for opacity (change in audit fees) and traditional proxies for idiosyncratic risk (emphasizing stock price crash). The 
unique aspect of examining audit fees as a proxy for opacity is that audit fees are determined by a third party (the external public accounting firms) which is put at risk by a company's operating results and disclosure choices. Our method presumes changes in audit fees not explained by publicly available information represent an auditor's private, client-specific informationidiosyncratic information known by management and the auditor, but unknown to investors. Should unexplained changes in audit fees be positively correlated with realizations of bad news events that occur between the negotiation and disclosure of the audit fee, then prompt disclosure of the negotiated audit fee would result in more timely communication of the information buildups that lead to "tipping points".

\subsection{The Codification of an Auditor's Private Knowledge in the Negotiated Audit Fee}

Generally Accepted Auditing Standards (GAAS) require auditors to alter the nature and extent of audit procedures performed and/or engagement staffing in response to client circumstances. For example, an auditor will alter the amount and mix of labor in response to the client engaging in a new set of complex transactions. No amount of audit work fully protects an auditor's financial exposure or reputation from some types of client events; for example, declines in client market share, client loss of a significant customer, lawsuits against the client, etc. An auditor's only recourse is to price protect herself by charging a risk premium in anticipation of such events.

O'Keefe, Simunic and Stein (1994) document that hours worked and the labor mix are sensitive to client operations and that audit fees paid are higher for riskier clients. Pratt and Stice (1994) and Johnstone and Bedard (2001) examine how client risk factors affect bid pricing, and find that accepted bids contain risk premia for both error and fraud risk after controlling for planned audit hours. These and many other papers are prima facie evidence that auditors utilize 
their forward-looking, client-specific, private information when negotiating audit fees. Or conversely, that negotiated audit fees impound auditors' client-specific, private information.

Several concurrent papers also examine the information contained in audit fees. ${ }^{4}$ Hribar, et al. (2010) demonstrates that audit fees may be used as an indicator of client's accounting quality. The document a relation between audit fees and future restatements and SEC comment letters. Picconi and Reynolds (2010) investigate the possibility of auditors knowing more than the market by examining the relation between unexplained audit fees and indicators of future performance — operating earnings, the likelihood of delisting and stock returns. They find evidence that the magnitude of unexplained audit fees is negatively related to future performance. This relation is significant only for the small firms in their sample. Stanley (2011) provides evidence of an inverse relation between unexpected audit fees and operating performance/solvency. These papers differ from our analysis in that we are examining the ability of the auditor to predict a specific market based tipping point event in the year under audit and not the yearlong decay in performance measured by annual accounting measures or twelve months of market returns subsequent to the year under audit.

\subsection{Idiosyncratic Risk}

Idiosyncratic risk is the risk that leads to a stock price change due to circumstances that are unique to a specific company as opposed to the market as a whole. The type of idiosyncratic risk that leads to increases in negotiated audit fees are those risks which are expected to result in negative outcomes - a decline in stock price, reduction in operating performance, lawsuit, etc. In general, investors can virtually eliminate idiosyncratic risk by forming a diversified portfolio.

\footnotetext{
${ }^{4}$ Hribar et al. (2010) investigate the role of unexplained audit fees as an alternate measure of accounting quality. They provide evidence that the unexplained portion of audit fees is useful in predicting restatements, fraud and SEC comment letters.
} 
Such diversification is a challenge for an audit firm because it cannot simply pick and choose clients from the population of companies. Each practice office and individual partner therein have profit and loss responsibility for a portfolio of audit clients which, at that level, is restricted by industry, geography, expertise, existing client base, and so on. Consequently, client acceptance and continuation decisions and fee negotiation are in large part made at the office and partner level (with firm oversight), resulting in service and pricing decisions resembling more of a client-by-client decision making process than an investor portfolio approach. As a result, audit pricing decisions are a function of the labor an auditor anticipates expending to render an opinion and a risk premium that compensates her for idiosyncratic risk.

\subsection{Baseline Empirical Model}

We examine the association between year-to-year changes in audit fees, proxies for idiosyncratic risk, and select company-specific characteristics in the following ordinary least squares regression:

$$
\% \Delta \text { Fees_Ind, }=\gamma_{0}+\gamma_{1} * \text { Idiosyncratic Risk }+\sum \gamma_{i} \text { CONTROLS }+e
$$

where $\% \Delta$ Fees is calculated as the percentage change in audit fees from year $t$ to $t-1$ divided by the $\mathrm{t}-1$ audit fee. ${ }^{5}$ We then median adjust this percentage based on the annual two digit SIC code to arrive at $\% \Delta$ Fees_Ind. The industry-adjustment mitigates the potentially spurious effects of macro-changes in audit fees, such as significant industry-specific changes in financial reporting

\footnotetext{
${ }^{5}$ We use the revised audit fees file from Audit Analytics database per Markelevich and Rosner (2009). This file contains the most complete audit fees reported. Differences are generally observed for smaller audit firms and are largely driven by differences in the timing of billing. This issue is addressed further in footnote 18 .
} 
regulations. ${ }^{6}$ This procedure ensures that our variables of interest are only explaining the abnormal movement in the change in audit fees in excess of the industry median. We winsorize the continuous variables at the $1^{\text {st }}$ and $99^{\text {th }}$ percentiles. Our t-statistics are estimated using clusteradjusted robust standard errors as prescribed in Petersen (2009), specifically we cluster on firm and year.

\subsection{Proxies for Idiosyncratic Risk}

Our primary measure of idiosyncratic risk is stock price crash (CRASH). We also consider two tradition proxies of idiosyncratic risk, credit rating downgrades (DOWNGRADE) and securities related lawsuits filed against the company (LAWSUIT). Since the audit fee is negotiated in the first quarter of the year under audit, all measures of idiosyncratic risk are computed from the end of the first quarter of the year under audit through the end of the first quarter of the following year. ${ }^{7}$

CRASH: This variable captures significant declines in stock price. It is estimated as in Hutton et al. (2009), equaling one when $\mathrm{W}_{\mathrm{it}}=\log \left(1+\mathrm{u}_{\mathrm{it}}\right)$ is more than 3.2 standard deviations below the annual mean for all firms in the same fiscal year and zero otherwise. The weekly residual stock return $u_{i t}$ is estimated as follows:

$$
R_{i t}=a_{0}+a_{1} * R_{m, t-2}+a_{2} * R_{m, t-1}+a_{3} * R_{m, t}+a_{4} * R_{m, t+1}+a_{5} * R_{m, t+2}+u_{i t}
$$

where $R_{i t}$ is a company's total raw cumulative weekly stock return for week $t, R_{m, t}$ is the

\footnotetext{
${ }^{6}$ The variable 'percentage change in audit fees' is akin the abnormal audit fees used in related work (Hribar et. al, 2010 and Picconi and Reynolds, 2010). Those papers estimate a model to capture expected audit fees while we use prior year audit fees as our measure for expected audit fees. Our estimate is more similar to change in logged audit fees, which is used in Stanley (2011). We control for the known operational and structural changes of the firm within our main regression. The benefit of this approach is that we do not force the auditor's response to operational and structural changes to be the same for all of their clients, which introduces measurement error into the change variable. Rather, we use a random walk approach and control for expected company-specific changes within the regression itself.

${ }^{7}$ The tenor of our results is unaffected by measuring our proxies for idiosyncratic risk from end of the first quarter though the end of the fourth quarter of the fiscal year under audit.
} 
cumulative value-weighted weekly stock return from CRSP (value-weighted return is reported daily and cumulated each week). We require at least 36 weeks of available data to estimate equation (2).

Like Kim and Zhang (2010), we also consider two variables closely related to CRASHskewness of residual returns (NSKEW) and the volatility of negative and positive idiosyncratic returns (DUVOL). NSKEW is calculated as the third moment of each company's weekly return over the entire fiscal year (Hutton et al. 2009). It measures the tendency of a company to disproportionately experience negative weekly stock returns over positive weekly stock returns. The distribution of weekly returns for companies with negative skewness would have a longer left tail if a company is more likely to experience negative stock returns. NSKEW= $\operatorname{SKEW}\left(\mathrm{W}_{\mathrm{it}}\right)$, where SKEW is the conditional skewness of a company's estimation period idiosyncratic weekly returns' distribution. In particular,

$$
\left.N S K E W_{i t}=-\left[n(n-1)^{3 / 2} \sum W_{i t}\right] /(n-1)(n-2)\left(\sum W_{i t}\right)^{3 / 2}\right)
$$

where $\mathrm{n}$ is the sample size. DUVOL is a measure of the relative volatility of idiosyncratic returns above its annual mean relative to volatility of idiosyncratic returns below its annual mean (Chen et al. 2001 and Kim and Zhang 2010). That is,

$$
D U V O L_{i t}=\log \left(\frac{\sigma\left(W_{i t} \mid W_{i t}<E\left(W_{i t}\right)\right)}{\sigma\left(W_{i t} \mid W_{i t}>=E\left(W_{i t}\right)\right)}\right)
$$

where $\sigma$ is the standard deviation operator, and $\mathrm{E}\left(\mathrm{W}_{\mathrm{it}}\right)$ denotes a mean of the annual distribution of $\mathrm{W}_{\mathrm{it}}$. The larger this measure, the more influence negative returns have on the company.

DOWNGRADE: Standard \& Poor's rates publicly traded debt. The extant literature has documented that these ratings are sticky, changing only when the accumulation of information reaches a "tipping point" (Jiang 2008). DOWNGRADE equals one when companies experience a long-term credit rating downgrade and zero otherwise. We obtain the S\&P credit ratings from 


\section{Compustat.}

LAWSUIT: Auditors are generally viewed as having "deep pockets" and are frequently named in securities-related lawsuits filed against their audit clients. Consequently, an auditor's exposure increases in tandem with a client's exposure to securities related class-action lawsuits (Palmrose 1999). LAWSUIT is an indicator variable equal to one if the company is subject to a new securities class-action suit during the year under audit (based on the lawsuit filing date) as reported in the Stanford Class-Action Clearinghouse database and zero otherwise.

\subsection{Control Variables}

We include several control variables in the regression which prior work has documented as being common determinants of audit fees. ${ }^{8}$ These controls are particularly important for us since they capture the likely increases in audit fees due to higher anticipated effort which we want to isolate from changes in idiosyncratic risk. Because the model that we are estimating is a change specification, many of the control variables identified in prior literature as determinates of the level of audit fees are not relevant, such as Big $\mathrm{N}$ auditor and auditor tenure. ${ }^{9}$

A client's financial condition significantly affects audit fees (Pratt and Stice 1994). Consequently, we control for the known changes in a company's operating performance with variables that represent the percentage change in the company's assets $\left(\% \Delta \mathrm{ASSETS}_{t}\right)$, sum of receivables and inventory $\left(\% \Delta I N V R E C_{t}\right)$, earnings $\left(\% \Delta E A R N_{t}\right)$, level of income from foreign operations $\left(\% \Delta \mathrm{FGN}_{t}\right)$, market-to-book ratio $\left(\% \Delta \mathrm{MTB}_{t}\right)$, leverage $\left(\% \Delta \mathrm{LEV}_{t}\right)$, special items $\left(\% \Delta \mathrm{SPEC}_{t}\right)$, and the percentage change in reported segments $\left(\% \Delta \mathrm{SEGM}_{t}\right)$. We also control for structural or operational changes that the auditor might be aware of because such events require

\footnotetext{
${ }^{8}$ Simunic (1980), Craswell et al. (1995), Ashbaugh et al. (2003), Whisenant et al. (2003), and Larker and Richardson (2004), to name a few.

${ }^{9}$ Un-tabulated tests indicate that the tenor of our results is unchanged after including controls for years of auditor tenure and an indicator variable for Big N status.
} 
incremental audit effort: the issuance of a modified or qualified audit opinion (MOD_OP ${ }_{t}$ ), the occurrence of a merger or acquisition during the year (ACQt), significant accounting irregularities $\left(\mathrm{IRREG}_{\mathrm{t}}\right)$, material internal control weaknesses $\left(\mathrm{WEAK}_{\mathrm{t}}\right)$, and stock issuances $\left(\mathrm{ISSUE}_{\mathrm{t}}\right) .{ }^{10}$ Detailed definitions of the control variables are presented in Appendix A.

\section{Sample selection and summary statistics}

\subsection{Sample selection}

The sample selection process is tabulated in Table 1 and originates with data collected from Audit Analytics. Audit Analytics provides systematic coverage beginning in 2000 of audit fee data and characteristics of auditors. Because we require two years of observable audit fee data to calculate a percentage change, our sample period is 2001 to 2010 . We begin with all available audit fee change data from Audit Analytics for which a matching CIK number is available in Compustat. This process yields 60,109 observations. The sample is further reduced when we calculate CRASH, leaving 45,101 observations. After requiring data needed to estimate the variables included in equation (1) from CRSP and Compustat, our sample is reduced to 36,80 observations. We eliminate all first year audit engagements because we are unable to calculate a percentage change in audit fees. Our final sample contains 35,349 observations.

\subsection{Descriptive Statistics}

Table 2 summarizes the descriptive statistics for all variables used in the analyses. Consistent with Ghosh and Pawlewitz (2009), the mean (median) $\% \Delta$ Fees and $\% \Delta$ Fees_Ind is $33 \%(8 \%)$ and $21 \%(0.00)$ respectively. Similar to the Hutton et al. (2009) sample, nineteen percent of the observed firm years have at least one crash event. Of the 9,041 companies in our sample, 3,685 (41\%) experience a crash event at least once during the decade of our sample

\footnotetext{
${ }^{10}$ Untabulated tests indicate that controlling for error-type restatements does not affect the tenor of our results.
} 
period. A crash event is associated with mean abnormal residual returns of approximately $-30 \%$. Consistent with Kim and Zhang (2010), the mean (median) $\mathrm{NSKEW}_{\mathrm{t}}$ is -0.07 (-0.09). We document that $15 \%$ of the firms in our sample experience a downgrade in their credit rating (DOWNGRADE ${ }_{t}$ ) which is similar to that reported in Lucas and Lonski (1992). Like Brown et al. (2005), we find that $2 \%$ of our sample experiences lawsuits.

Our control variables further describe the companies in our sample. Acquisitions $\left(\mathrm{ACQ}_{\mathrm{t}}\right)$ occur in $9 \%$ of our observations while stock issuances $\left(\mathrm{ISSUE}_{\mathrm{t}}\right)$ occur $4 \%$ of the time. ${ }^{11} \mathrm{An}$ internal control weakness $\left(\mathrm{WEAK}_{\mathrm{t}}\right)$ is reported for $4 \%$ of the sample and an accounting irregularity $\left(\mathrm{IRREG}_{\mathrm{t}}\right.$ ) occurs $1 \%$ of the time.${ }^{12}$ An audit opinion other than a clean opinion (MOD_OP $\left.{ }_{t}\right)$ is issued $45 \%$ of the time. ${ }^{13}$ Assets $\left(\% \triangle \mathrm{ASSET}_{\mathrm{t}}\right)$, inventory and receivables $\left(\% \Delta \mathrm{INVREC}_{\mathrm{t}}\right)$, and leverage $\left(\% \Delta \mathrm{LEV}_{\mathrm{t}}\right)$ are increasing on average while earnings $\left(\% \Delta \mathrm{EARN}_{\mathrm{t}}\right)$ and foreign income $\left(\% \Delta \mathrm{FGN}_{\mathrm{t}}\right)$ appear to be declining. The latter is consistent with the recessionary period of 2007-09 included in our sample.

\subsection{Additional descriptive statistics}

Table 3 presents additional descriptive statistics for $\mathrm{CRASH}_{\mathrm{t}}$, our primary test variable and the change in audit fees $(\% \Delta$ Fees and $\% \Delta$ Fees_Ind $)$. Panel A reports that crashes occur evenly over the sample period. Panel B finds that crashes occur more often in Petroleum \& Coal

\footnotetext{
${ }^{11}$ The average season equity offerings (SEO) announcement effect documented in numerous studies is - $2 \%$ (Ritter, 2003). Thus, given that CRASH is defined by presence of very extreme negative stock returns which average $-30 \%$ (see Figure 2), SEO announcement effects are not confound our results.

${ }^{12}$ The identification of material weaknesses came about as a result of the Sarbanes Oxley Act (2002) This section of the Act did not become effective until August of 2003; therefore, this variable does not exist prior to 2004. To address this we set all missing data prior to the effective date equal to zero.

${ }^{13}$ Our untabulated analysis indicates that almost all of these modified opinions are unqualified opinions with explanatory language (e.g. due to an accounting change or issuance of going concern opinion). In general, our untabulated analyses show that between 2000 and 2011, Compustat shows a total of 32 qualified, adverse or disclaimer of audit opinions, which represents $0.05 \%$ of total population of audit opinions.
} 
Products (2900) and Business Services (7300) industries. ${ }^{14}$ These two industries individually represent in excess of $10 \%$ of our sample individually. The tenor of our main results is unchanged when we use the unadjusted percentage change in audit fees $\left(\% \Delta \mathrm{Fees}_{\mathrm{t}}\right)$ and include industry-level fixed effects as a control.

Table 3 Panel C presents descriptive statistics for changes in the percentage of audit fees (\% $\%$ Fees) and industry adjusted audit fees $(\% \Delta$ Fees_Ind $)$ by year. The directional movement in the fee percentages through time is similar for both the adjusted and unadjusted rates. It is apparent that fees in general are increasing through time and that the increase accelerated in 2004 and then returned to normal levels in 2007. The acceleration observed in 2004 is most likely due to the implementation of the Sarbanes Oxley Act of 2002 (SOX) which led to significant increases in the amount of audit related work performed. The bulk of this work was performed in one year and requires updating in subsequent periods. Per Financial Executives International's $7^{\text {th }}$ SOX Compliance Survey (2008), SOX implementation led to a spike in fees in 2003 and 2004 followed be declining maintenance costs. Because of the significant implementation costs of SOX (2002) in terms of increased audit fees, we estimate our main analysis for the full sample and for two sub samples. In the subsamples we treat 2003-2006 as the SOX period sample and the time periods surrounding 2003-2006 as the non-SOX sample. Decomposing our sample helps us to ensure that our results are not driven by the increase in audit fees precipitated by the implementation of SOX (2002). Our un-tabulated results show that our inferences are qualitatively un-affected by the sample used.

\subsection{Pearson Correlations}

\footnotetext{
${ }^{14}$ The industry clustering that is documented in Panel B of Table 3 mirrors the industry clustering contained in Audit Analytics prior to our sample construction. Therefore we have no reason to believe that the sample selection process is leading to the industry clustering that is observed.
} 
Table 4 summarizes the pairwise Pearson correlations of all variables used in the study. Both $\% \Delta F e e s$ and $\% \Delta F e e s \_$Ind are positively correlated with $\mathrm{CRASH}_{\mathrm{t}}, \mathrm{NSKEW}_{\mathrm{t}}, \mathrm{DUVOL}_{\mathrm{t}}$, and LAWSUIT $_{\mathrm{t}}(\mathrm{p}<0.001)$ providing preliminary evidence of the relation between increases in audit fees and our proxies for idiosyncratic risk. $\mathrm{CRASH}_{\mathrm{t}}$ is positively correlated $(\mathrm{p}<0.001)$ with the alternative test variables $\operatorname{NSKEW}_{t}(24 \%)$, DUVOL $_{t}(25 \%)$, DOWNGRADE $_{t}(22 \%)$, and LAWSUIT $_{\mathrm{t}}(9 \%)$; suggesting that CRASH and the other variables are measuring the revelation of varying types of company-specific bad news. In our empirical analysis we consider each of these variables independently to determine if negotiated audit fees are sensitive to different aspects of company specific bad news.

\section{Empirical results}

\subsection{Primary Analysis}

Table 5 reports the estimation of equation (1) for CRASH (Model 1), NSKEW (Model 2) and DUVOL (Model 3). The variables of interest are significantly positive and economically meaningful $(\mathrm{p}$-value $=0.01)$. The coefficient on the $\mathrm{CRASH}_{\mathrm{t}}$ variable is 0.05 , indicating that a crash event is associated with a 5\% increase in the industry-adjusted audit fee. We obtain similar results for the variables NSKEW and DUVOL which have significant coefficients of 0.02 and 0.04 , respectively. Taken together, these results indicate that increases in audit fees occur in years when clients reach tipping points that lead to crash events as measured by CRASH, NSKEW and DUVOL.

The control variables included in the analysis reported in Table 5 behave in a manner consistent with conventional wisdom and the extant audit fee literature. The results are consistent

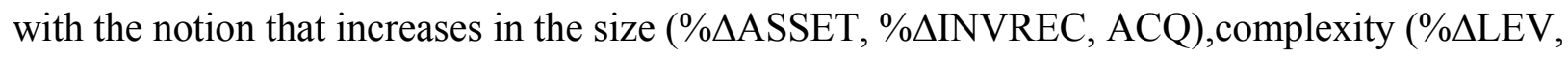


$\% \triangle$ SPEC), and risk of misstatement (WEAK, IRREG ) of companies lead to increases in audit

fees — client characteristics that would result in the auditor performing additional audit work. ${ }^{15}$ The fact that the majority of these variables load suggests that our controls for changes in audit effort are explaining significant portions of the change in fees.

Table 6 reports the results using the alternate proxies for idiosyncratic risk—downgrades in credit ratings and the filing of security-related lawsuits. The results are consistent with those reported for CRASH in the Table 5. Specifically, downgrades and lawsuits are associated with increased abnormal fees of $4 \%$ and $11 \%$ in our sample. The control variables in Table 6 appear to respond similarly to those in Table 5. Finding consistent results with credit downgrades and the filing of security lawsuits triangulate the findings and conclusions from Table 5. Taken together, the results reported in Tables 5 and 6 are consistent with auditors predicting future informational "tipping points" and engaging in a form of price protection.

\section{Additional Analysis and Robustness Tests}

\subsection{Reported fees as a proxy for negotiated fees}

In this subsection, we provide evidence that the audit fee negotiated in the first quarter of the year under audit and documented in the engagement letter is, de facto, disclosed as the audit fee paid retrospectively in the first quarter of the fiscal year following the year audited proxy statement, making the audit fee paid a reasonable proxy for the audit fee negotiated.

\subsubsection{The ability of auditors to increase the negotiated audit fee}

The most recent academic work on fee structure is Palmroses' (1989) analysis of circa 1980 audits where both fixed fee and cost plus contracts where observed. Copley and Doucet

\footnotetext{
${ }^{15}$ See, for example, Whisenant et al. (2003), Raghunandan and Rama (2006), Hribar et al. (2010), Ashbaugh et al. (2003), Krishnan et al. (2009) for levels models and Ferguson et al. (2007) for change models.
} 
(1993) find that $79 \%$ of 1985 external governmental audits were fixed fee contracts. We have not found any academic or professional articles since Palmrose (1989) and Copley and Doucet (1993) that document the contract type used in practice let alone during our sample period for audits of public companies. Given the scant public documentation of contract type and to avoid relying on common knowledge, we conducted formal interviews with five senior audit partners from three of the four Big 4 public accounting firms, each responsible for negotiating audit fees with public companies. In short, all audit partners unequivocally stated audit fees paid rarely deviate from the negotiated audit fee. The audit partners concurred with the description of the fee negotiation process used throughout this paper and stated unanimously and unambiguously their inability to increase negotiated fees unless the audit firm and client agree to supplement the negotiated fee for unexpected, client-necessitated cost overruns — additional audit firm work must be performed. The partners indicated an aversion to being viewed as trying to "milk" their clients for additional fees and a general practice of avoiding renegotiation of the fee for fear of jeopardizing the multi-year client relationship. This perspective is consistent with Hackenbrack and Hogan's (2005) result that realization rates are significantly lower on engagements marred by client imposed delays, i.e., it is hard for firms to pass on unexpected costs.

\subsubsection{Fee increases due to additional audit work}

Audit contracts are fixed fee contracts where increases must be mutually agreed to by the auditor and client based solely on unexpected increases in the scope of the audit work. To assure the identified crash events do not led to an increase in audit effort and, consequently a renegotiated audit fee, we selected a random sample 200 of company-years with crash events and used Factiva to identify the cause of the crash (Figure 2). We find that the driver of a majority of the crash events is performance-related, missing market expectations, walking down market 
forecasts and downward revisions to analyst's forecasts (52\%). Product failure and operational changes $(11 \%)$ are the second leading cause of crash events. They include clinical trial failures, structural changes in company's industry, loss of major customer, etc. M\&A announcements (9\%) represent announcements of future acquisitions as well as the revelation of increasing costs or failure of a previously announced merger. We do control for the acquisition of a target firm $\left(\mathrm{ACQ}_{t}\right)$ in our analysis as it is expected to increase the amount of audit work performed. Nonfinancial lawsuit (7\%) relate to the investigation of price fixing, bribery in foreign countries, loss of patent related lawsuits, etc. None of the events in this category are related to securities/financial reporting. Equity/debt offerings and restatements each represent $6 \%$ of the crash events. As with M\&A, the crash event is associated with an announcement of the client's intent to issue equity/debt or a need to restate and not the amount of audit work associated with these events. We control for the issuance of new stock (ISSUE $t$ ) and the restatement announcement $\left(\mathrm{IRREG}_{\mathrm{t}}\right)$ in our multivariate analysis. Thus, crash events do not precipitate an expansion in the scope of the financial statement audit and a consequent increase in the negotiated audit fee.

\subsubsection{Association between increased fees and next period crash events}

We calculate the change in audit fees from year $t-1$ to year $t$ and examine its relation to crash events occurring in year $\mathrm{t}+1$, relaxing the assumption that reported fees are a proxy for negotiated fees. To do this, we estimate the following:

$\% \Delta$ Fees_Ind $=\gamma_{0}+\gamma_{1} *$ Idiosyncratic Risk $k_{t}+\gamma_{2}{ }^{*}$ Idiosyncratic Risk $t_{t+1}+\sum \gamma_{i}$ CONTROLS $+e$ (5) Equation (1) is augmented by adding the idiosyncratic risk proxy for year $t+1$. The coefficient $\gamma_{2}$ will be significantly positive if current year audit fees contain information about the subsequent year's idiosyncratic risk of clients. 
In untablulated results, the coefficient on $\mathrm{CRASH}_{\mathrm{t}}$ and $\mathrm{CRASH}_{\mathrm{t}+1}$ are significantly positive (p-value $<0.01$ ) with coefficients of 5.0\% and 3.0\%, respectively. These results suggest that on average industry-adjusted changes in audit fees predict both contemporaneous and next year's crashes. We estimate equation 5 using NSKEW and DUVOL and find the coefficients on the variables of interest to also be significantly positive at $2 \%(5 \%)$ in both year $t$ and $t+1$ for NSKEW (DUVOL). In summary, this analysis (and those in sections 5.1.1 and 5.1.2) provides strong evidence that fee renegotiations during the year under audit are not driving the reported results.

\subsection{Pre-vs. Post-SOX years}

Hutton et al. (2008) find that their inference with regard to the ability of abnormal accruals to forecast crash events dissipates after the adoption of Sarbanes Oxley (2002). We reran our analysis including an indicator variable SOX that equals 1 for years after 2004 and zero otherwise. We find that the main effect on CRASH is significant, while interaction CRASH*SOX is not. We then ran our CRASH regression in sub-samples that include 2000-2003 (pre SOX) and 2004-2010 (post SOX) years, separately, and obtain a significant and positive coefficient on CRASH in both periods. This suggests that the result hold for both pre and postSOX periods, and that the economic relationship between CRASH and industry-adjusted changes in audit fees is not sensitive to the adoption of SOX.

\subsection{Demise of Arthur Andersen}

During our sample period, Arthur Andersen, one of the Big N auditing firms failed. Chaney and Philipich (2002) and Krisnamurthy et al. (2006) provide evidence that Arthur Andersen clients experienced significant reputational losses that were manifested in stock price declines. In addition, Krishnan (2005) indicates that clients of the Houston office of Arthur 
Andersen were systematically less conservative in their accounting choices, which could make them more susceptible to stock price crashes. We reexamine our main results excluding the 561 Arthur Andersen observations and find that the tenor of our results is not affected.

\section{Conclusion}

Market participants learn the audit fee paid retrospectively in the first quarter of the fiscal year following the year audited. As a result, roughly a year lapses between the auditor and the client fee negotiation and investors learning the audit fee. Audit fees for the current year contain potentially valuable information about company-specific risks. We empirically examine the relation between year-to-year changes in the audit fee paid and stock price crashes that occur over the 12 months between the negotiation and disclosure of the audit fee (year $\mathrm{t}$ ), and the following 12 months (year $\mathrm{t}+1$ ). Our analysis addresses the question of whether more timely disclosure of the negotiated audit fee would decrease the level of company-specific opacity, thereby reducing the build-up of undisclosed bad news that leads to crashes.

We find that the change in the negotiated audit fee is positively related to the occurrence of a stock price crash in both year $\mathrm{t}$ and year $\mathrm{t}+1$ after controlling for factors that affect changes in planned audit effort. On average, companies that experience a stock price crash can expect its auditor to negotiate a $5 \%$ increase in the audit fee in advance of the crash event. Thus, auditors appear to predict future information "tipping points" and engage in a form of price protection. This result holds for several alternative measures, additional control variables, and model specifications. Moreover, this result holds both before and after SOX implementation.

Company-specific opacity is greater than perhaps necessary as a result of the timing of the audit fee disclosure. Our results suggest that prompt disclosure of the negotiated audit fee 
would decrease the level of company-specific opacity and result in a decline in the frequency of "tipping points" being reached. Lack of prompt disclosure cannot be attributed to the information not being available or the absence of a vehicle through which the information can be disclosed. The negotiated audit fee is objective, stated in the engagement letter, and known when the definitive proxy statement is filed the first quarter of the year under audit. Our empirical findings are the first step in documenting the economically relevant information contained in negotiated fees and demonstrating that auditors' price protect in response to their understanding of the risks and rewards their clients face. The analysis does not address the trade-offs between the economic benefits documented and the potential costs like making a currently cooperative negotiation process more contentious. Future work is needed to understand these trade-offs. 


\section{Appendix A: Definition of Control Variables}

$\% \Delta$ Fees $_{\mathrm{t}} \quad$ The percentage change in audit fees from year $\mathrm{t}$ to $\mathrm{t}-1$ divided by the $\mathrm{t}-1$ audit fee (Audit Analytics Audit_Fees)

$\% \Delta$ Fees_Ind $\quad$ Industry median adjusted $\% \Delta$ Fees $_{\mathrm{t}}$ based on the annual two digit SIC code.

$\mathrm{CRASH}_{\mathrm{t}} \quad$ Equaling one when $\mathrm{W}_{\mathrm{it}}=\log \left(1+\mathrm{u}_{\mathrm{it}}\right)$ is more than 3.2 standard deviations below the annual mean for all firms in the same fiscal year and zero otherwise. The weekly residual stock return $u_{i t}$ is estimated as follows:

$$
R_{i t}=a_{0}+a_{1} * R_{m, t-2}+a_{2} * R_{m, t-1}+a_{3} * R_{m, t}+a_{4} * R_{m, t+1}+a_{5} * R_{m, t+2}+u_{i t}
$$

where $R_{i t}$ is a company's total raw cumulative weekly stock return for week $t, R_{m, t}$ is the cumulative value-weighted weekly stock return from CRSP (value-weighted return is reported daily and cumulated each week).

$\mathrm{NSKEW}_{\mathrm{t}} \quad$ Equals $-\mathrm{SKEW}\left(\mathrm{W}_{\mathrm{it}}\right)$, where SKEW is the conditional skewness of a company's estimation period idiosyncratic weekly returns' distribution. In particular:

$$
\left.N S K E W_{i t}=-\left[n(n-1)^{3 / 2} \sum W_{i t}\right] /(n-1)(n-2)\left(\sum W_{i t}\right)^{3 / 2}\right)
$$

$\mathrm{W}$ is defined above in the definition for $\mathrm{CRASH}_{\mathrm{t}}$

DUVOL $_{t}$

$$
D U V O L_{i t}=\log \left(\frac{\sigma\left(W_{i t} \mid W_{i t}<E\left(W_{i t}\right)\right)}{\sigma\left(W_{i t} \mid W_{i t}>=E\left(W_{i t}\right)\right)}\right)
$$

$\mathrm{W}$ is defined above in the definition for $\mathrm{CRASH}_{\mathrm{t}}$ where $\sigma$ is the standard deviation operator, and $\mathrm{E}\left(\mathrm{W}_{\mathrm{it}}\right)$ denotes a mean of the annual distribution of $\mathrm{W}_{\mathrm{it}}$. The larger this measure, the more influence negative returns have on the company.

DOWNGRADE $_{t} \quad$ An indicator variable equal to 1 when companies experience a long-term credit rating downgrade and zero otherwise (Compustat SPDRC).

LAWSUIT $_{t} \quad$ An indicator variable equal to one if the company is subject to a new securities classaction litigation (based on the lawsuit filing date) as reported in the Stanford ClassAction Clearinghouse database and zero otherwise.

$\mathrm{ACQ}_{\mathrm{t}} \quad$ An indicator variable equal to 1 if the company acquired a company in fiscal year $\mathrm{t}$ (Compustat, AQS).

ISSUE $_{\mathrm{t}} \quad$ An indicator variable equal to 1 if the company issued stock in fiscal year $\mathrm{t}$ per SDC database.

WEAK $_{t} \quad$ An indicator variable equal to 1 if the auditor found internal controls to be ineffective (Audit Analytics 404 Opinion file, IC_OP_TYPE='N'). 
IRREG $_{t} \quad$ An indicator variable equal to 1 if the firm appears in either of the GAO $(2002,2006)$ restatement reports or in the Audit Analytics database and where the restatement is described as the result of an accounting irregularity by Hennes et al. (2008) or Audit Analytics and zero otherwise.

MOD_OP $P_{t} \quad$ An indicator variable equal to 1 if the audit report is adverse, qualified, or unqualified with explanatory language and zero otherwise (Compustat, AUOP).

$\% \triangle \mathrm{ASSET}_{\mathrm{t}} \quad$ Annual percentage change in assets (Compustat, AT)

$\% \triangle I N V R E C_{t} \quad$ Annual percentage change in the sum of receivables and inventory (Compustat, RECT+INVT).

$\% \triangle \mathrm{EARN}_{\mathrm{t}} \quad$ Annual percentage change in earnings (Compustat, IB).

$\% \Delta \mathrm{FGN}_{\mathrm{t}} \quad$ Annual percentage change in foreign income (Compustat, PIFO).

$\% \Delta \mathrm{MTB}_{\mathrm{t}} \quad$ Annual percentage change in the market-to-book ratio (Compustat, PRCC_F*CSHO/CE).

$\% \Delta \mathrm{LEV}_{\mathrm{t}} \quad$ Annual percentage change in total dollar amount of liabilities (Compustat, LT).

$\% \triangle \mathrm{SPEC}_{t} \quad$ Annual percentage change in special items (Compustat, SPI)

$\% \Delta \mathrm{SEGM}_{\mathrm{t}} \quad$ Annual percentage change in the number of reported segments (Compustat Segment Database, BUSSEG). 


\section{References}

Ashbaugh-Skaife, H., R. LaFond, and B. Mayhew. 2003. Do non-audit services compromise auditor independence: Further evidence. The Accounting Review, 78 (3): 611-639.

Botosan, C. 1997. Disclosure level and the cost of equity capital. The Accounting Review, 72, (3): 323-349.

Botosan, C. and M. Plumlee. 2002. A re-examination of disclosure level and the expected cost of equity capital. Journal of Accounting Research, 40(1): 21-40.

Brown, S., S. Hillegeist, and K. Lo. 2005. Management forecasts and litigation risk. Working paper. University of Maryland.

Chaney, P. and K. Philipich. 2002. Shredded reputation: the cost of audit failure. Journal of Accounting Research, 40(4): 1221-1245.

Chen, J., H. Hong, J. Stein (2001). Forecasting crashes: trading volume, past returns, and conditional skewness in stock prices. Journal of Financial Economics, 61, 345-381

Copley, P. A. and M.S. Doucet. 1993. Auditor Tenure, Fixed Fee Contracts, and the Supply of Substandard Single AuditsPublic Budgeting \& Finance, 13 (3) 23-35.

Craswell, A. T., Francis, J. R., \& Taylor, S. L. 1995. Auditor brand name reputations and industry specialization. Journal of Accounting and Economics 20(3): 297-322.

Diamond, D. and R. Verrecchia. 1991. Disclosure, liquidity and cost of capital. Journal of Finance, 46(4): 1325-1359.

Ferguson, A., C. Lennox, and S. Taylor. 2007. A dynamic model of audit fees changes. Working Paper. University of New South Wales.

Financial Executives International. 2008. FEI Survey: Average 2007 SOX Compliance Cost $\$ 1.7$ Million. April 30. Financial Executives International. Accessed on October 10, 2011 at: http://fei.mediaroom.com/index.php?s=43\&item=204.

Frankel, R. M. McNichols, and P. Wilson. 1995. Discretionary disclosure and external financing. The Accounting Review, 70(1): 135-150.

Ghosh, A. and R. Pawlewitz. 2009. The impact of regulation on auditor fees: evidence from the Sarbanes-Oxley act. Auditing: Journal of Practice and Theory, 28(2): 171-197.

Hackenbrack, K. and C. Hogan. 2005. Client retention and engagement-level pricing. Auditing: Journal of Practice and Theory, 24(1): 7-20. 
Healy, P. and C. Palepu. 2001. Information asymmetry, corporate disclosure and capital markets. Journal of Accounting and Economics, 31: 405-440.

Heflin, F., K. Shaw and J. Wild. 2005. Disclosure quality and market liquidity: the effect of depth quotes and order sizes. Contemporary Accounting Research, 22(4): 829865.

Hennes, K., A. Leone, and B. Miller. 2008. The importance of distinguishing errors from irregularities in restatement research: The Case of Restatements and CEO/CFO Turnover. The Accounting Review, 83(6): 1487-1519.

Hribar, P., T. Kravet, and R. Wilson. 2010. A new measure of accounting quality. Working Paper. University of Iowa.

Hutton, A., Marcus, A.J., Tehranian, H. 2009. Opaque financial reports, $\mathrm{R}^{2}$, and crash risk. Journal of Financial Economics 94: 67-86.

Jiang, J. 2008. Beating earnings benchmarks and the cost of debt. The Accounting Review 83 (2): $377-416$.

Jin, L. and Myers, S.C. 2006. $\mathrm{R}^{2}$ around the world: new theory and new tests. Journal of Financial Economics 79: 257-292.

Johnstone, K, Bedard, J. 2001. Engagement planning, bid pricing and client response: The effects of risk and market context in initial attest engagements The Accounting Review 76: 199-220.

Kothari, S.P, S. Shu, and P. Wysocki. 2009. Do managers withhold bad news? Journal of Accounting Research, 47(1): 241-276.

Kim, O. and R. Verrecchia. 1994. Market liquidity and volume around earnings announcements. Journal of Accounting and Economics, 17: 41-67.

Kim, J., Y. Li, and L. Zhang. 2010. Corporate tax avoidance and stock price crash risk: firmlevel analysis. Journal of Financial Economics forthcoming.

Kim, J. and L. Zhang. 2010. Does accounting conservatism reduce stock price crash risk? Firm level evidence. Working Paper. City University of Hong Kong.

Krishnan, G. 2005. Did Houston clients of Arthur Andersen recognize publicly available bad news in a timely fashion? Contemporary Accounting Research, 22(1): 165-204.

Krisnamurthy, S. J. Zhou, and H. Zhou. 2006. Auditor reputation, auditor independence, and the stock-market impact of Andersen's indictment on its client firms. Contemporary Accounting Research, 23(2): 265-490. 
Krishnan, G., P. Sengupta, and M. Pevzner. 2009. How do auditors view managers' disclosure strategy? A case of management earnings forecast. Working Paper. George Mason University.

Lambert, R., C. Leuz, and R. Verrecchia. 2007. Accounting information, disclosure, and the cost of capital. Journal of Accounting Research, 45(2): 385-420.

Lang, M. and R. Lundholm. 1996. Corporate disclosure policies and analyst behavior. The Accounting Review, 71(4): 467-492.

Lang, M. and R. Lundholm. 2000. Voluntary disclosure and equity offerings: reducing information asymmetry or hyping the stock? Contemporary Accounting Research, 17(4): 623-662

Lucas, D. and J. Lonski. 1992. Changes in corporate credit quality 1970-1990. Journal of Fixed Income, 1(4): 7-14.

Markelevich, A. and R. Rosner. 2010. Original and revised auditor fee data. Working Paper. Suffolk University.

O'Keefe, T., D. Simunic and M. Stein. 1994. The production of audit services: evidence from a major public accounting firm. Journal of Accounting Research, 32 (2), 241-261.

Palmrose, Z., 1989. The relation of audit contract type to audit fees and hours. The Accounting Review, 65 (3) 488-499.

Palmrose, Z., 1999. Empirical Research on Auditor Litigation: Considerations and Data. Studies in Accounting Research \#33, American Accounting Association: Sarasota, FL.

Picconi, M. and J.K. Reynolds. 2010. Do auditors know more than the market? College of William and Mary working paper.

Petersen, M.A. 2009. Estimating standard errors in finance panel data sets: comparing approaches. Review of Financial Studies 22(1): 435-480.

Pevzner, M. 2007. Management earnings forecasts, information asymmetry, and liquidity: An empirical investigation. Unpublished working paper. George Mason University.

Pratt, J., and J. Stice. 1994. The effects of client characteristics on auditor litigation risk judgments, required audit evidence. The Accounting Review, 69 (4): 639-656.

Raghunandan, K., and D. Rama. 2006. SOX section 404 material weakness disclosures and audit fees. Auditing: Journal of Practice and Theory, 25(1): 99-114. 
Ritter, Jay R., 2003. Investment banking and securities issuance. Handbook of the Economics of Finance, edited by G.M. Constantinides, M. Harris, and R. M. Stulz 255-306. North Holland, England. Elsevier.

Sengupta, P. 1998. Corporate disclosure quality and the cost of debt. The Accounting Review, 73(4): 459-474.

Simunic, D. 1980. The pricing of audit services: theory and evidence, Journal of Accounting Research, 18: 161-90.

Stanley, J. 2011. Is the audit fee disclosure a leading indicator of clients' business risk? Auditing: A Journal of Practice \& Theory, 30 (3) 157-179.

Welker, M. 1995. Disclosure Policy, information asymmetry and liquidity in equity markets. Contemporary Accounting Research, Spring, 11(2): 805-827.

Whisenant S., S. Sankaraguruswamy, and K. Raghunandan. 2003. Evidence on the joint determination of audit and non-audit fees. Journal of Accounting Research 41 (4): $721-$ 744. 


\section{Table 1 \\ Sample Selection}

The sample period spans 2001-2010 and is based on all available data from Compustat, Audit Analytics, CRSP, and Stanford Class-Action Securities Litigation Database. All continuous variables are winsorized at $1^{\text {st }}$ and $99^{\text {th }}$ percentiles.

\section{Sample Selection Process}

(1) Company years covered by Audit Analytics Revised Audit Fee file with available industry-adjusted audit fees changes and a matching CIK number in Compustat

60,109

(2) CRSP Coverage and availability of CRASH

45,101

(3) Availability of Compustat controls

36,800

(4) First year Engagements

35,349 


\section{Table 2}

\section{Descriptive Statistics}

Table reports the descriptive statistics for 35,349 firm year observations from 2001-2010. The sample selection process is described in Table 1. All variables are defined in the Appendix A.

\begin{tabular}{|c|c|c|c|c|c|c|}
\hline VARIABLE & $\mathbf{N}$ & MEAN & STD & Q1 & MEDIAN & Q3 \\
\hline$\% \Delta$ Fees $_{t}$ & 35,349 & 0.33 & 0.93 & -0.05 & 0.08 & 0.33 \\
\hline$\% \Delta$ Fees_Ind ${ }_{t}$ & 35,349 & 0.21 & 0.89 & -0.13 & 0.00 & 0.21 \\
\hline CRASH $_{t}$ & 35,349 & 0.19 & 0.39 & 0.00 & 0.00 & 0.00 \\
\hline DUVOL $_{t}$ & 35,118 & -0.06 & 0.37 & -0.31 & -0.07 & 0.17 \\
\hline NSKEW $_{t}$ & 35,119 & -0.07 & 0.81 & -0.52 & -0.09 & 0.34 \\
\hline DOWNGRADE $_{t}$ & 10,372 & 0.15 & 0.36 & 0.00 & 0.00 & 0.00 \\
\hline LAWSUIT $_{t}$ & 35,349 & 0.02 & 0.13 & 0.00 & 0.00 & 0.00 \\
\hline $\mathrm{ACQ}_{\mathrm{t}}$ & 35,349 & 0.09 & 0.29 & 0.00 & 0.00 & 0.00 \\
\hline ISSUE $_{t}$ & 35,349 & 0.04 & 0.20 & 0.00 & 0.00 & 0.00 \\
\hline WEAK $_{t}$ & 35,349 & 0.04 & 0.19 & 0.00 & 0.00 & 0.00 \\
\hline IRREG $_{t}$ & 35,349 & 0.01 & 0.08 & 0.00 & 0.00 & 0.00 \\
\hline MOD_OP & 35,349 & 0.45 & 0.50 & 0.00 & 0.00 & 1.00 \\
\hline$\% \Delta \mathrm{ASSET}_{\mathrm{t}}$ & 35,349 & 0.10 & 0.35 & -0.05 & 0.05 & 0.17 \\
\hline$\% \Delta I N V R E C_{t}$ & 35,349 & 0.15 & 0.57 & -0.09 & 0.05 & 0.23 \\
\hline$\% \Delta$ EARN $_{t}$ & 35,349 & -0.25 & 3.78 & -0.72 & -0.04 & 0.40 \\
\hline$\% \Delta F G N_{t}$ & 35,349 & -0.02 & 1.15 & 0.00 & 0.00 & 0.00 \\
\hline$\% \Delta \mathrm{MTB}_{t}$ & 35,349 & 0.13 & 0.96 & -0.28 & -0.01 & 0.30 \\
\hline$\% \Delta L E V_{t}$ & 35,349 & 0.17 & 0.58 & -0.08 & 0.04 & 0.21 \\
\hline$\% \Delta S P E C_{t}$ & 35,349 & 0.28 & 6.84 & -1.00 & -0.55 & 0.00 \\
\hline$\% \Delta$ SEGM $_{t}$ & 35,349 & -0.18 & 0.35 & -0.33 & 0.00 & 0.00 \\
\hline
\end{tabular}


Table 3

Additional Descriptive Statistics for CRASH and Percentage of Audit Fees

Table reports the descriptive statistics for 35,349 firm year observations from 2001-2010. Panel A (B) reports the frequency of sample observations with at least one CRASH on an annual (industry) basis. Panel C summarizes the annual mean and median raw and industry adjusted percentage change in audit fees. The sample selection process is described in Table 1. All variables are defined in Appendix A.

Panel A: Annual Distribution of Companies with At Least One CRASH vs. Annual Distribution of All Observations in the Sample

\begin{tabular}{|c|cr|cr|}
\hline Year & $\begin{array}{c}\text { Obs. with at } \\
\text { Least One CRASH }\end{array}$ & $\begin{array}{r}\text { \% of } \\
\text { Total }\end{array}$ & $\begin{array}{c}\text { All } \\
\text { Observations }\end{array}$ & $\begin{array}{r}\text { \% of } \\
\text { Total }\end{array}$ \\
\hline $\mathbf{2 0 0 1}$ & 501 & $7 \%$ & 2,586 & $7 \%$ \\
$\mathbf{2 0 0 2}$ & 689 & $10 \%$ & 3,049 & $9 \%$ \\
$\mathbf{2 0 0 3}$ & 725 & $11 \%$ & 3,745 & $11 \%$ \\
$\mathbf{2 0 0 4}$ & 779 & $11 \%$ & 3,757 & $11 \%$ \\
$\mathbf{2 0 0 5}$ & 781 & $11 \%$ & 3,673 & $10 \%$ \\
$\mathbf{2 0 0 6}$ & 773 & $11 \%$ & 3,700 & $10 \%$ \\
$\mathbf{2 0 0 7}$ & 718 & $11 \%$ & 3,621 & $10 \%$ \\
$\mathbf{2 0 0 8}$ & 825 & $12 \%$ & 3,898 & $11 \%$ \\
$\mathbf{2 0 0 9}$ & 620 & $9 \%$ & 3,775 & $11 \%$ \\
$\mathbf{2 0 1 0}$ & 421 & $6 \%$ & 3,545 & $10 \%$ \\
\hline Total & $\mathbf{6 , 8 3 2}$ & $\mathbf{1 0 0 \%}$ & $\mathbf{3 5 , 3 4 9}$ & $\mathbf{1 0 0 \%}$ \\
\hline
\end{tabular}


Table 3, continued

Additional Descriptive Statistics for CRASH and Percentage of Audit Fees

Panel B: Number and Percentage of Observations with At Least one CRASH by Industry

\begin{tabular}{|c|c|c|c|c|c|}
\hline $\begin{array}{l}\text { Two Digit } \\
\text { SIC Code }\end{array}$ & Industry & $\begin{array}{c}\text { Obs. with at } \\
\text { least one CRASH }\end{array}$ & $\begin{array}{l}\% \text { of } \\
\text { Total }\end{array}$ & $\begin{array}{c}\text { All } \\
\text { Observations }\end{array}$ & $\begin{array}{l}\% \text { of } \\
\text { Total }\end{array}$ \\
\hline 28 & $\begin{array}{l}\text { Chemicals and Allied } \\
\text { Products }\end{array}$ & 49 & $0.72 \%$ & 3,059 & $8.65 \%$ \\
\hline 29 & $\begin{array}{l}\text { Petroleum and Coal } \\
\text { Products }\end{array}$ & 875 & $12.81 \%$ & 213 & $0.60 \%$ \\
\hline 35 & $\begin{array}{l}\text { Industrial Machinery } \\
\text { \& Equipment }\end{array}$ & 60 & $0.88 \%$ & 2,006 & $5.67 \%$ \\
\hline 36 & $\begin{array}{l}\text { Electronic \& Other } \\
\text { Electric Equipment }\end{array}$ & 405 & $5.93 \%$ & 2,962 & $8.38 \%$ \\
\hline 38 & $\begin{array}{l}\text { Instruments Related } \\
\text { Products }\end{array}$ & 561 & $8.21 \%$ & 2,265 & $6.41 \%$ \\
\hline \multirow[t]{3}{*}{73} & Business Services & 1,173 & $17.17 \%$ & 4,145 & $11.73 \%$ \\
\hline & Other Industries & 3,709 & $54.29 \%$ & 20,699 & $58.56 \%$ \\
\hline & Total & 6,832 & $100.00 \%$ & 35,349 & $100.00 \%$ \\
\hline
\end{tabular}


Table 3, continued

Additional Descriptive Statistics for CRASH and Percentage of Audit Fees

Panel C: Annual Distribution of Unadjusted and Adjusted percentage change in Audit Fees.

\begin{tabular}{|c|c|c|c|c|c|}
\hline \multirow{2}{*}{ Year } & \multirow{2}{*}{$\begin{array}{l}\text { Number of } \\
\text { Observations }\end{array}$} & \multicolumn{2}{|c|}{$\% \Delta$ Fees $_{t}$} & \multicolumn{2}{|c|}{$\% \Delta$ Fees_Ind ${ }_{t}$} \\
\hline & & Mean & Median & Mean & Median \\
\hline 2001 & 2,586 & $20 \%$ & $9 \%$ & $12 \%$ & $1 \%$ \\
\hline 2002 & 3,049 & $36 \%$ & $19 \%$ & $19 \%$ & $3 \%$ \\
\hline 2003 & 3,745 & $51 \%$ & $19 \%$ & $35 \%$ & $3 \%$ \\
\hline 2004 & 3,757 & $87 \%$ & $48 \%$ & $46 \%$ & $9 \%$ \\
\hline 2005 & 3,673 & $56 \%$ & $15 \%$ & $4 \%$ & $2 \%$ \\
\hline 2006 & 3,700 & $30 \%$ & $8 \%$ & $2 \%$ & $-1 \%$ \\
\hline 2007 & 3,621 & $23 \%$ & $5 \%$ & $17 \%$ & $-1 \%$ \\
\hline 2008 & 3,898 & $12 \%$ & $2 \%$ & $9 \%$ & $0 \%$ \\
\hline 2009 & 3,775 & $3 \%$ & $-3 \%$ & $5 \%$ & $0 \%$ \\
\hline 2010 & 3,545 & $4 \%$ & $-1 \%$ & $5 \%$ & $0 \%$ \\
\hline Total & 35,349 & $33 \%$ & $8 \%$ & $21 \%$ & $\mathbf{0} \%$ \\
\hline
\end{tabular}


Table 4

Pearson Correlations

The Table presents the correlation Pearson correlations between the variables examined in our analyses. Correlations that are significant at the 0.05 level are bolded. Table reports the descriptive statistics for 35,349 firm year observations from 2001-2010. The sample selection process is described in Table 1. All variables are defined in Appendix A.

\begin{tabular}{ccccccccc}
\hline & & $\mathbf{1}$ & $\mathbf{2}$ & $\mathbf{3}$ & $\mathbf{4}$ & $\mathbf{5}$ & $\mathbf{6}$ & $\mathbf{7}$ \\
\hline $\mathbf{1}$ & $\% \Delta$ Fees $_{\mathrm{t}}$ & - & & & & & & \\
$\mathbf{2}$ & $\% \Delta$ Fees_Ind $_{\mathrm{t}}$ & $\mathbf{0 . 9 9}$ & - & & & & \\
$\mathbf{3}$ & CRASH $_{\mathrm{t}}$ & $\mathbf{0 . 0 3}$ & $\mathbf{0 . 0 3}$ & - & & & \\
$\mathbf{4}$ & NSKEW $_{\mathrm{t}}$ & $\mathbf{0 . 0 3}$ & $\mathbf{0 . 0 2}$ & $\mathbf{0 . 2 4}$ & - & & & \\
$\mathbf{5}$ & DUVOL $_{\mathrm{t}}$ & $\mathbf{0 . 0 3}$ & $\mathbf{0 . 0 2}$ & $\mathbf{0 . 2 5}$ & $\mathbf{0 . 9 6}$ & - & & \\
$\mathbf{6}$ & DOWNGRADE $_{\mathrm{t}}$ & 0.01 & 0.02 & $\mathbf{0 . 2 2}$ & $\mathbf{0 . 0 2}$ & 0.01 & - & \\
$\mathbf{7}$ & LAWSUIT $_{\mathrm{t}}$ & $\mathbf{0 . 0 2}$ & $\mathbf{0 . 0 2}$ & $\mathbf{0 . 0 9}$ & $\mathbf{0 . 0 8}$ & $\mathbf{0 . 0 8}$ & $\mathbf{0 . 0 6}$ & - \\
\hline
\end{tabular}


Table 5

\section{The Association of Audit Fees Changes and Stock Price Crash Risk}

The models presented report t-statistic estimated using standard errors cluster-adjusted by companion a firm level, and including year-fixed effects per Petersen (2009). All continuous variables are winsorized at $1^{\text {st }}$ and $99^{\text {th }}$ percentiles $*, * *, * * *$ denote two-tail significance levels of $0.1,0.05$, and 0.01 , respectively. All variables are defined in Appendix A

\begin{tabular}{|c|c|c|c|c|c|c|}
\hline \multirow[b]{2}{*}{ Variables } & \multicolumn{2}{|c|}{ Model 1} & \multicolumn{2}{|c|}{ Model 2} & \multicolumn{2}{|c|}{ Model 3} \\
\hline & $\begin{array}{l}\text { Coefficient } \\
\text { Estimate }\end{array}$ & t-stat & $\begin{array}{l}\text { Coefficient } \\
\text { Estimate }\end{array}$ & t-stat & $\begin{array}{l}\text { Coefficient } \\
\text { Estimate }\end{array}$ & t-stat \\
\hline$C^{C R A S H_{t}}$ & $0.05^{* * *}$ & 4.13 & & & & \\
\hline NSKE $W_{t}$ & & & $0.02^{* * *}$ & 3.29 & & \\
\hline DUVOL $_{t}$ & & & & & $0.04 * * *$ & 3.34 \\
\hline $\mathbf{A C Q}_{\mathrm{t}}$ & $0.15^{* * *}$ & 8.45 & $0.15^{* * *}$ & 8.28 & $0.15^{* * *}$ & 8.28 \\
\hline ISSUE $_{t}$ & 0 & 0.09 & -0.01 & -0.36 & -0.01 & -0.36 \\
\hline WEAK $_{t}$ & $0.54 * * *$ & 13.79 & $0.53^{* * *}$ & 13.65 & $0.53^{* * *}$ & 13.64 \\
\hline IRREG $_{t}$ & $0.63^{* * *}$ & 4.95 & $0.39^{* * *}$ & 5.09 & $0.39^{* * *}$ & 5.1 \\
\hline MOD_OP & 0 & -0.99 & -0.01 & -1.17 & -0.01 & -1.15 \\
\hline$\% \Delta$ ASSET $_{t}$ & $0.21 * * *$ & $9,33 * * *$ & $0.21 * * *$ & 9.26 & $0.21^{* * *}$ & 9.32 \\
\hline$\% \Delta$ INVREC $_{t}$ & $0.04 * * *$ & 3.52 & $0.04 * * *$ & 3.58 & $0.04 * * *$ & 3.57 \\
\hline$\% \Delta$ EARN $_{t}$ & 0 & 1.41 & 0 & 1.33 & 0 & 1.34 \\
\hline$\% \Delta F G N_{t}$ & 0 & 0.46 & 0 & 0.36 & 0 & 0.37 \\
\hline$\% \Delta M T B_{t}$ & -0.01 & -1.27 & 0 & -0.75 & 0 & -0.73 \\
\hline$\% \Delta L E V_{t}$ & $0.06^{* * *}$ & 4.95 & $0.06^{* * *}$ & 4.95 & $0.06^{* * *}$ & 4.9 \\
\hline$\% \Delta$ SPEC $_{\mathrm{t}}$ & $0.00 * *$ & 2.06 & $0.00 * *$ & 2.09 & $0.00 * *$ & 2.09 \\
\hline$\% \Delta$ SEGM & 0.01 & 0.61 & 0.01 & 0.32 & 0.01 & 0.33 \\
\hline INTERCEPT & $0.07^{* * *}$ & 6.13 & $0.09^{* * *}$ & 7.37 & $0.09^{* * *}$ & 7.47 \\
\hline $\mathbf{N}$ & 35,349 & & 35,119 & & 35,118 & \\
\hline R-sq & 0.06 & & 0.06 & & 0.06 & \\
\hline
\end{tabular}


Table 6

The Association of Audit Fees Changes and Alternative Test Variables

All models include cluster-adjusted company-level standard errors and year fixed effects per Petersen (2009). All continuous variables are winsorized at $1^{\text {st }}$ and $99^{\text {th }}$ percentiles. ${ }^{*}, * *, * * *$ denote two-tail significance levels of 0.1 , 0.05 , and 0.01 , respectively. The sample selection process is described in Table 1 . All variables are defined in Appendix A.

\begin{tabular}{|c|c|c|c|c|}
\hline & \multicolumn{2}{|c|}{ Model 1} & \multicolumn{2}{|c|}{ Model 2} \\
\hline Variables & $\begin{array}{c}\text { Coefficient } \\
\text { Estimate }\end{array}$ & t-statistic & $\begin{array}{l}\text { Coefficient } \\
\text { Estimate }\end{array}$ & t-statistic \\
\hline DOWNGRADE ${ }_{t}$ & $0.04^{*}$ & 1.94 & & \\
\hline LAWSUIT $_{t}$ & & & $0.11 * * *$ & 3.94 \\
\hline $\mathbf{A C Q}_{\mathrm{t}}$ & $0.10 * * *$ & 3.32 & $0.15 * * *$ & 8.40 \\
\hline ISSUE $_{t}$ & -0.01 & -0.43 & -0.00 & -0.22 \\
\hline WEAK $_{t}$ & $0.33 * * *$ & 5.66 & $0.54 * * *$ & 13.86 \\
\hline IRREG $_{t}$ & $0.39 * * *$ & 2.58 & $0.62 * * *$ & 4.86 \\
\hline MOD_OPt & 0.00 & 0.30 & -0.01 & -1.08 \\
\hline$\% \Delta$ ASSET $_{t}$ & $0.25 * * *$ & 6.6 & $0.20 * * *$ & 11.52 \\
\hline$\% \Delta I N V R E C_{t}$ & $0.08 * * *$ & 3.37 & $0.04 * * *$ & 3.93 \\
\hline$\% \Delta E A R N_{t}$ & 0 & 0.34 & 0 & 1.37 \\
\hline$\% \Delta F G N_{t}$ & -0.01 & -1.52 & 0 & 0.39 \\
\hline$\% \Delta \mathrm{MTB}_{\mathrm{t}}$ & 0.01 & 0.94 & -0.01 & -1.18 \\
\hline$\% \Delta \mathrm{LEV}_{\mathrm{t}}$ & $0.10^{*}$ & 1.91 & $0.07 *$ & 1.94 \\
\hline$\% \Delta \mathrm{SPEC}_{\mathrm{t}}$ & 0.00 & 0.93 & 0.00 & 2.13 \\
\hline$\% \Delta S E G M_{t}$ & $0.05 * *$ & 2.10 & 0.01 & 0.46 \\
\hline INTERCEPT & $0.08 * * *$ & 3.49 & $0.08 * * *$ & 6.74 \\
\hline $\mathbf{N}$ & 10,372 & & 35,349 & \\
\hline R-sq & 0.07 & & 0.06 & \\
\hline
\end{tabular}




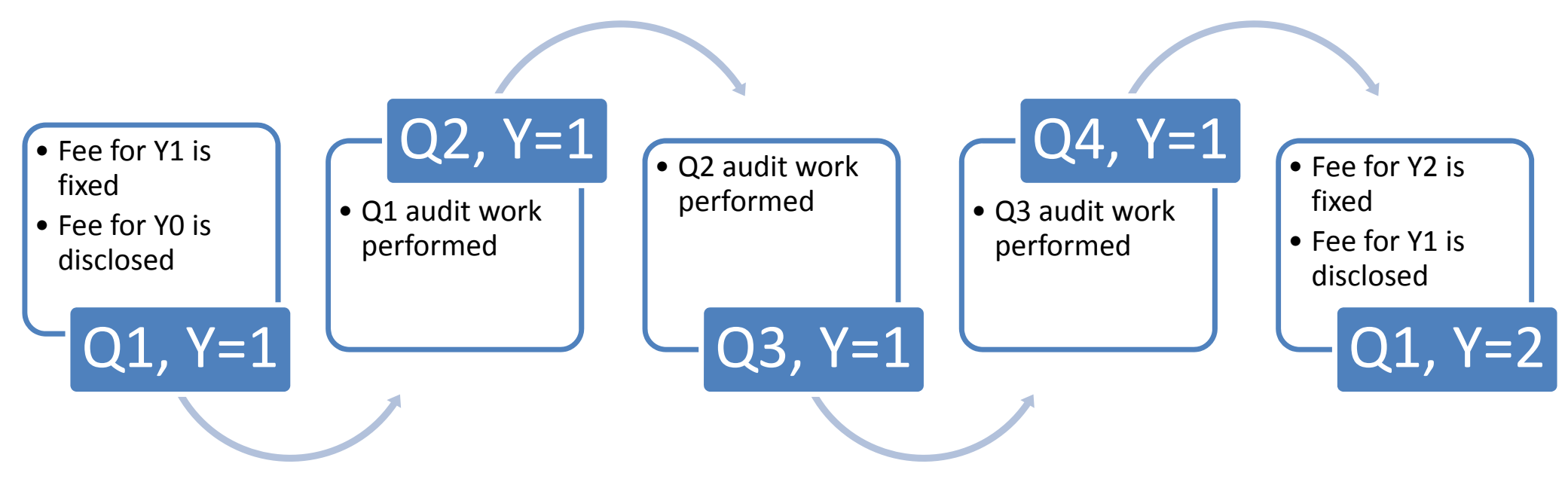




\section{Figure 2: Distribution of CRASH Causes}

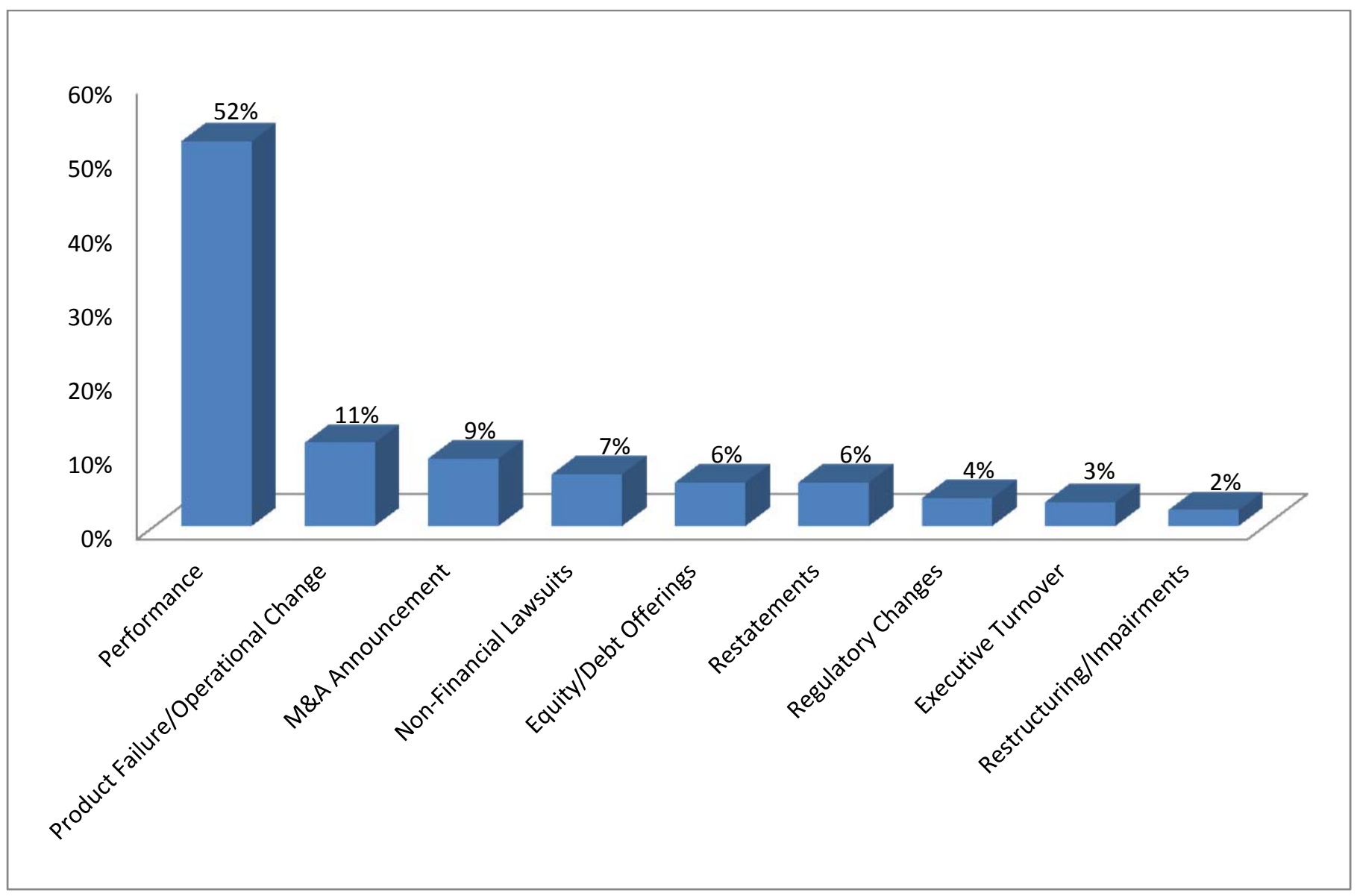

Performance - Company failed to meet market expectations or experienced a downward revision in market expectations.

Product Failure/Operational Change - Company experienced a failed clinical trial or the removal of a product from the market. Also, operational changes such as a natural disaster, loss of a major customer, etc.

M\&A Announcement - Company announced its intention to acquire another company or an issue related to an M\&A transaction. We control for the acquisition of a target firm in our multivariate analyses $\left(\mathrm{ACQ}_{\mathrm{t}}\right)$.

Non-Financial Lawsuits - The filing or resolution of a non-financial reporting-related lawsuit (price fixing, bribes). Equity/Debt Offerings - Company announced a seasoned equity offering or a debt offering. Credit downgrades are also included in this category. We control for the issuance of new equity in our multivariate analyses (ISSUE $\mathrm{t}_{\mathrm{t}}$

Restatements-Company announced a restatement or announced it is under investigation by the SEC for a financial reporting issue. We control for restatements that meet the definition of an irregularity in our multivariate analyses ( IRREG $_{\mathrm{t}}$ ).

Regulatory Changes - Government agency changed a regulation.

Executive Turnover - CEO/CFO left the company.

Restructuring/Impairments - Company has disclosed a plan for restructuring or that it has incurred a major asset impairment.

Note: These events do not result in an unexpected increase in audit effort during the year under audit, so do not precipitate a mutually agreed upon increase in audit fees. We specifically control for the completion of M\&As $\left(A C Q_{t}\right)$, issuance of new shares of equity $\left(\mathrm{ISSUE}_{t}\right)$ and restatement announcements (IRREG ${ }_{t}$ ) in our multivariate analyses. The crash event occurs due to the announcement of these items and not the acquisition of a target firm or the audit work required to execute the restatement. The issuance of new shares of equity is not expected to result in additional audit work. 